\title{
Etiologia zaburzeń spektrum autyzmu - przegląd koncepcji
}

AbstraCt: Lidia Szmania, Etiologia zaburzeń spektrum autyzmu - przegląd koncepcji [The etiology of autism - a review of current concepts]. Interdyscyplinarne Konteksty Pedagogiki Specjalnej, nr 11, Poznań 2015. Pp. 93-123. Adam Mickiewicz University Press. ISSN 2300-391X

Researches are still trying to figure out what is the real cause of autism. In the years several major concepts conceming patogenical mechanisms of this disease has not been determined. However, none of them turned out to be entirely good. The purpose of this article is to systematically review the concepts and select the ones that have been proven empirically.

KEY WORDS: autism spectrum disorders, autism etiology, cencepts etiological

Zaburzenia spektrum autyzmu od lat skupiają uwagę wielu naukowców, dzięki czemu zakres wiedzy dotyczącej specyfiki funkcjonowania zarówno dzieci, jak i dorosłych osób z autyzmem powiększa się. Ma to istotne znaczenie nie tylko dla nauki, ale także praktyki - terapii osób z zaburzeniami spektrum autyzmu, której rezultaty przekładają się $\mathrm{w}$ konsekwencji na podniesienie jakości życia tych osób. Nieustannie podejmowane są próby ustalenia etiologii autyzmu, przez wiele lat intensywnej pracy wyodrębniono koncepcje mówiące o mechanizmach patogennych zaburzeń autystycznych. Jednak do tej pory nie udało się określić jednorodnej, 
spójnej koncepcji, która wyczerpująco tłumaczyłaby przyczyny owego zaburzenia ${ }^{1}$. Jak postulują liczni badacze, prawdopodobnie wynika to z faktu, iż etiologia zaburzeń spektrum autyzmu jest skomplikowana i wieloczynnikowa².

Współczesne doniesienia naukowe wpisują autyzm w grupę zaburzeń o podłożu neurorozwojowym, w której fundamentalne znaczenie mają dysfunkcje w budowie i funkcjonowaniu mózgu. Zwraca się również uwagę, iż nie bez znaczenia są czynniki natury genetycznej i środowiskowej3. Przez wiele lat $w$ myśleniu o przyczynach zaburzeń spektrum autyzmu dominowały jednak czynniki o charakterze psychologicznym, przypisujące główną rolę $\mathrm{w}$ powstawaniu zaburzeń rodzicom dzieci ${ }^{4}$.

Celem niniejszego opracowania jest usystematyzowanie koncepcji etiologicznych zaburzeń spektrum autyzmu, a także zwrócenie szczególnej uwagi na koncepcje potwierdzone empirycznie.

\section{Czynniki psychogenne}

Rozpatrywanie etiologii autyzmu z perspektywy podejścia psychoanalitycznego jest najstarszą próbą zrozumienia przyczyn tego zaburzenia. Koncepcje wpisujące się w nurt psychologiczny były

1 P. Gołaska, Etiologia zaburzeń ze spektrum autyzmu. Przegląd wybranych koncepcji, [w:] Psychiatria i psychologia kliniczna, nr 1, 2013, s. 8; M. Talaroska, A. Florkowski, P. Gałecki, K. Zboralski, Psychologiczne koncepcje rozwoju autyzmu, [w:] Autyzm epidemiologia, diagnoza i terapia, red. T. Pietras, A. Witusik, P. Gałecki, Wydawnictwo Continuo, Wrocław 2010, s. 99.

2 E. Pisula, Autyzm. Od Badań mózgu do praktyki psychologicznej, Gdańskie Wydawnictwo Psychologiczne, Sopot 2012, s. 57.

${ }^{3}$ E. Pisula, Autyzm. Przyczyny, symptomy, terapia, Wydawnictwo HARMONIA, Gdańsk 2010b, s. 25; B. Winczura, Jak funkcjonuje mózg dzieci z autyzmem? Neurobiologiczne ścieżki zaburzeń autystycznych, [w:] Dziecko chore. Zagadnienia biopsychiczne i pedagogiczne, red. B. Cytowska, B. Winczura, Oficyna Wydawnicza „Impuls”, Kraków 2008, s. 17.

${ }^{4}$ E. Pisula, Małe dziecko z autyzmem, Gdańskie Wydawnictwo Psychologiczne, Sopot 2010a, s. 22; E. Pisula, Autyzm. Przyczyny, symptomy, terapia..., s. 25. 
najbardziej rozpowszechnione $\mathrm{w}$ połowie $\mathrm{XX} \mathrm{w}$. Zgodnie $\mathrm{z}$ ich założeniami autyzm to zaburzenie o podłożu psychogennym, stanowiące odpowiedź dziecka na zastane, niesprzyjające środowisko5. $\mathrm{W}$ koncepcjach tych bardzo istotną rolę odgrywa obserwacja rozwoju dziecka rozpoczynająca się już w okresie życia płodowego, która obejmuje badanie kolejnych faz rozwoju świadomości, od niezróżnicowanej matrycy, do odróżnienia poczucia ja od innych obiektów $\mathrm{w}$ otaczającym świecie. Analizie poddawane są również mechanizmy poznawcze, behawioralne i emocjonalne, warunkujące prawidłowy przebieg rozwoju' ${ }^{6}$.

Koncepcje psychogenne zbudowane są na przekonaniu, iż autyzm jest skutkiem pojawienia się $\mathrm{w}$ trakcie rozwoju dziecka czynnika traumatyzującego, wynikającego $\mathrm{z}$ zaistnienia nieprawidłowych relacji między dzieckiem a opiekunem podstawowym, najczęściej matką7. Wśród sytuacji mogących wywołać traumę u dziecka psychoanalitycy wymieniają m.in.:

- poród, podczas którego dziecko doświadcza silnego lęku, spowodowanego nagłym przejściem z ciepłego i bezpiecznego środowiska, w którym rozwijało się do tej pory, w środowisko zupełnie obce, nieprzyjazne,

- oddzielenia dziecka od matki tuż po narodzinach,

- pobyt $w$ inkubatorze,

- psychiczne odtrącenie dziecka przez matkę,

- powtórne lub długotrwałe przebywanie dziecka w szpitalu,

- oddanie dziecka do domu dziecka ${ }^{8}$.

Leo Kanner uznawany jest za jednego z głównych przedstawicieli psychoanalitycznego spojrzenia na etiologię autyzmu. W arty-

${ }^{5}$ E. Pisula, D. Danielewicz, Terapia i edukacja osób z autyzmem - historia $i$ dzień dzisiejszy, [w:] Terapia i edukacja osób z autyzmem. Wybrane zagadnienia, red. D. Danielewicz, E. Pisula, Wydawnictwo APS, Warszawa 2003, s. 9.

${ }^{6}$ M. Talaroska, A. Florkowski, P. Gałecki, K. Zboralski, op. cit., s. 100.

7 M. Suchowierska, P. Ostaszewski, P. Bąbel, Terapia behawioralna dzieci z autyzmem. Teoria, badania i praktyka stosowanej analizy zachowania, Gdańskie Wydawnictwo Psychologiczne, Sopot 2012, s. 28.

${ }^{8}$ M. Młynarska, Autyzm w ujęciu psycholingwistycznym: terapia dyskursywna a teoria umystu, Wydawnictwo Uniwersytetu Wrocławskiego, Wrocław 2008, s. 89. 
kule z 1943 r. zawarł opis sylwetki psychologicznej rodziców dzieci z zaburzeniami spektrum autyzmu, którym przypisał takie cechy jak: chłód emocjonalny, sztywność w funkcjonowaniu, przeintelektualizowanie, a także zachowania obsesyjne ${ }^{9}$. Był on zdania, iż źródłem autyzmu jest "zimna”, nadmiernie racjonalna, odrzucająca noworodka, deprywująca jego emocjonalne potrzeby, matka ${ }^{10}$. $\mathrm{W}$ pracy tej napisał również, iż dzieci $\mathrm{z}$ tego typu zaburzeniami rodzą się z "niezdolnością do formowania zwyczajnych, zdeterminowanych biologicznie emocjonalnych kontaktów z innymi osobami"11, co wskazuje, iż poza cechami osobowości rodziców dostrzegał neurobiologiczne podłoże zaburzeń spektrum autyzmu. Mimo to psychiatrzy przyjęli kannerowski opis osobowości rodziców dzieci z autyzmem jako swoisty wzór, a inni psychoanalitycy potwierdzali związek między „zimną", sztywną osobowością rodziców a autyzmem występującym u dzieci'i2.

Kontynuatorem myśli Leo Kannera był Bruno Bettelheim. Jego zdaniem zachowania autystyczne stanowią mechanizm obronny, uruchamiany przez dzieci $\mathrm{w}$ sytuacjach skrajnego zagrożenia płynącego z najbliższego otoczenia. Reakcje te, choć często ekstremalne, pomagają dzieciom poradzić sobie z traumatycznymi doświadczeniami, które przeżywają. Zatem zgodnie ze sposobem myślenia badacza wnioskować można, iż zaburzenia spektrum autyzmu mają charakter funkcjonalny ${ }^{13}$. Bruno Bettelheim w sposób bezpośredni upatrywał źródeł negatywnych doświadczeń w rodzicach, zwłasz-

${ }^{9}$ L. Bobkowicz-Lewartowska, Autyzm dziecięcy, zagadnienia diagnozy $i$ terapii, Oficyna Wydawnicza „Impuls”, Kraków 2000, s. 25.

${ }^{10}$ M. Talaroska, A. Florkowski, P. Gałecki, K. Zboralski, op. cit., s. 101; B. Winczura, Dziecko z autyzmem. Terapia deficytów poznawczych a teoria umystu, Oficyna Wydawnicza „Impuls”, Kraków 2008, s. 350.

11 B. Winczura, Dziecko z autyzmem..., s. 17.

12 A. Wojciechowska, Koncepcje autyzmu i problemy diagnostyczne - przeglad literatury, [w:] Poznańska pedagogika specjalna. Tradycje - osiagnięcia - perspektywy, red. W. Dykcik, A. Twardowski, Wydawnictwo Naukowe UAM, Poznań 2006, s. 314.

${ }^{13}$ E. Pisula, D. Danielewicz, op. cit., s. 10; M. Talaroska, A. Florkowski, P. Gałecki, K. Zboralski, op. cit., s. 102. 
cza matkach. Wśród przyczyn autyzmu wymieniał: „psychotyczną więź matki z dzieckiem, zaburzenia osobowości obojga rodziców, trudności w nawiązywaniu kontaktu emocjonalnego między matką i dzieckiem"14. Podkreślał, iż na skutek doświadczenia odrzucenia i deprywacji ze strony opiekuna dzieci tracą zaufanie do świata zewnętrznego. Zakłócona więź stanowi zatem przyczynę społecznego wycofania się dziecka, wyizolowania, ucieczki do własnego, wewnętrznego świata ${ }^{15}$.

Kolejnym reprezentantem psychoanalitycznych poglądów była Melanie Klein. Doszukiwała się ona przyczyn występowania zaburzeń spektrum autyzmu w niedojrzałym i słabo zintegrowanym ego dziecka ${ }^{16}$. Zgodnie z założeniami prezentowanymi przez M. Klein funkcjonowanie psychiczne noworodka przechodzi przez kilka faz rozwoju i ma charakter psychotyczny. W pierwszej fazie niemowlę znajduje się w pozycji paranoidalno-schizoidalnej17, w której główną emocją przeżywaną przez dziecko jest silny lęk. Pojawia się on, ponieważ „w wyniku działania projekcji i introjekcji ego pozostaje w relacji z dwoma obiektami: piersią idealną i piersią prześladującą"18. Druga faza rozwoju została nazwana przez autorkę pozycją depresyjną, na tym etapie dziecko spostrzega już matkę całościowo, reaguje na całą osobę, a nie, jak miało to miejsce dotychczas, wybiórczo np. na jej ręce czy głos. Zdaniem badaczki, jeżeli na tym etapie rozwoju dojdzie do zakłóceń w relacji matka - dziecko, przeżywany przez dziecko lęk, może spowodować wystąpienie u niego reakcji obronnych, przejawiających się m.in. w postaci autystycznego zachowania. Melanie Klein uważa, iż rezultatem trwale zaburzonego kontaktu jest stan adaptacji schizoidalnej, która polega na wycofaniu się dziecka z relacji interpersonalnych. Wycofanie to, według

14 B. Winczura, Dziecko z autyzmem..., s. 351.

${ }^{15}$ L. Bobkowicz-Lewartowska, op. cit., s. 27; E. Pisula, D. Danielewicz, op. cit., s. 10.

16 B. Winczura, Dziecko z autyzmem..., s. 351.

17 Pojęcia „pozycja paranoidalno-schizoidalna” oraz „pozycja depresyjna” są stosowane w pracach Melanie Klein (por.: L. Bobkowicz-Lewartowska, op. cit., s. 21).

18 L. Bobkowicz-Lewartowska, op. cit., s. 21. 
autorki, ma charakter obronny. Podkreśla ona również, iż negatywne doświadczenia wyniesione $\mathrm{z}$ wczesnego dzieciństwa wpływają na sposób funkcjonowania osób w dorosłości ${ }^{19}$.

W podobny sposób etiologię zaburzeń spektrum autyzmu tłumaczy Margaret Mahler. Uważa ona, tak jak inni autorzy, iż u podstaw zaburzeń autystycznych leży nieprawidłowa relacja matki i dziecka. Dodaje jednocześnie, iż powstałe zakłócenia negatywnie wpływają na przebieg procesu indywiduacji. Margaret Mahler była zdania, iż stan autyzmu występuje w rozwoju każdego dziecka i trwa przez kilka pierwszych tygodni życia. Noworodek reaguje wtedy wyłącznie na własne potrzeby, a świat zewnętrzny nie jest dla niego interesujący - nie tworzy ono relacji z obiektami i nie różnicuje ich. Około 2. miesiąca życia niemowlę zaczyna spostrzegać, iż matka stanowi obiekt zaspokajania jego potrzeb. Zaczyna tworzyć z nią symbiotyczną więź, dla której charakterystyczny jest „brak rozróżniania pomiędzy self a obiektem oraz istnienie połączonej reprezentacji umysłowej self i obiektu" ${ }^{20}$. Autorka podkreśla, iż pozytywne doświadczenia wyniesione $\mathrm{z}$ tej fazy rozwoju związane z czułą opieką i troską matki stanowią kluczową rolę dla procesu separacji. Proces ten polega na zauważeniu przez dziecko, że ono i matka stanowią dwie odrębne osoby. Uważa ona tym samym, iż zaburzenia spektrum autyzmu pojawiają się u dziecka na skutek nieprawidłowości zaistniałych właśnie w fazie symbiozy. W konsekwencji dziecko nie posiada świadomości istnienia zewnętrznej rzeczywistości, a także tworzenia swojego własnego schematu i obrazu ja21.

Współczesna psychoanalityk dziecięca Francis Tustin postuluje, iż autyzm jest jednym z pierwszych etapów rozwojowych każdego dziecka. Stanowi on przejaw radzenia sobie $\mathrm{z}$ trudną dla noworodka sytuacją - rozdzielenia jego ciała od ciała matki. Rezultatem zaistniałej sytuacji jest występujące $u$ dziecka poczucie utraty własne-

${ }^{19}$ M. Talaroska, A. Florkowski, P. Gałecki, K. Zboralski, op. cit., s. 100-101.

${ }^{20}$ L. Bobkowicz-Lewartowska, op. cit., s. 22

${ }^{21}$ M. Młynarska, op. cit., s. 89 
go ciała22. Francis Tustin zwraca uwagą na czas, w którym dochodzi do separacji, sugerując, iż dziecko nie jest na nią jeszcze gotowe: „W autyzmie zbyt wcześnie doznana frustracja naraża ego dziecka na doświadczenie braku obiektu, zanim było ono zdolne do relacji z obiektem na poziomie wewnętrznym reprezentacji fantazji czy halucynacji" 23. Podczas separacji dziecko doświadcza poczucia silnego lęku przed obcym, niebezpiecznym, nieznanym światem zewnętrznym. Spoglądając z takiej perspektywy, wystąpienie u dziecka zachowań autystycznych staje się czymś naturalnym, bowiem broni ono siebie, swoją własną wrażliwość. Zachowania te mogą jednak przejeść w stan patologii, gdy stanowią jedyną możliwą strategię radzenia sobie $\mathrm{z}$ sytuacją trudną. Koncepcja przestawiona przez F. Tustin jest istotna, ponieważ stanowi próbę połączenia (w myśleniu o przyczynach zaburzeń spektrum autyzmu) czynników psychologicznych z neurobiologicznymi. Patrząc w taki sposób, autyzm jest wynikiem reakcji z poziomu ośrodkowego układu nerwowego na traumę przeżywaną przez dziecko we wczesnym dzieciństwie ${ }^{24}$.

Nieco inaczej autystyczną obronę postrzega John Hochman. W tej koncepcji dziecko w sposób aktywny i celowy wycofuje się ze świata zewnętrznego, gdyż odbiera wszelkie przejawy aktywności intelektualnej jako atak na siebie, co w konsekwencji destrukcyjnie wpływa na jego rozwój. Zdaniem J. Hochmana autyzm jest „postawą aktywnego wycofania się z kontaktu z rzeczywistością, która dziecka nie satysfakcjonuje, ponadto jest unikaniem wszelkiej zmiany i zafascynowaniem czynnościami mechanicznego powtarzania"25. Źródeł tej sytuacji również upatruje się w postawach rodziców, których działania stanowią mechanizm napędowy w spirali zachowań autystycznych. To oni - zgodnie z prezentowaną koncepcją - nie potrafią stworzyć interesującego dla dziecka środowi-

22 B. Winczura, Dziecko z autyzmem..., s. 351

${ }^{23}$ L. Bobkowicz-Lewartowska, op. cit., s. 24

${ }^{24}$ M. Talaroska, A. Florkowski, P. Gałecki, K. Zboralski, op. cit., s. 102.

25 B. Winczura, Dziecko z autyzmem..., s. 351. 
ska rozwojowego. Starają się stymulować jego rozwój poznawczy, czego dziecko nie toleruje, przez co zachwiane jest jego poczucie bezpieczeństwa. Dziecko poprzez powtarzające się, mechaniczne działania stara się przywrócić sobie równowagę i zaspokoić swoje potrzeby 26 .

Kolejnym przedstawicielem psychoanalitycznego sposobu rozumowania etiologii zaburzeń spektrum autyzmu jest Niko Tinbergen. Postrzega on autyzm nie jako stan, lecz proces prowadzący od normy do patologii. Autor koncepcji uważa, iż zachowanie autystyczne pojawia się u dziecka $\mathrm{w}$ wyniku poczucia zagrożenia wywołującego lęk. Badacz podkreśla, iż dziecko pierwszych zdobywa pierwsze doświadczenia społeczne w kontakcie z matką ${ }^{27}$. Mówi on o dwóch drogach rozwoju społecznego, zbudowanych właśnie na tego rodzaju doświadczeniach. Pierwszą z nich jest radość z kontaktu, której konsekwencją jest występująca u dziecka reakcja dążenia do. Pozytywne doświadczenia powodują, iż dziecko chętnie nawiązuje kontakt fizyczny, wzrokowy, naśladuje innych ludzi. Natomiast druga, wynika z doświadczeń negatywnych, które N. Tinbergen nazywa strachem przed kontaktem. Skutkuje on reakcjami odwrotnymi: dziecko unika kontaktów społecznych i zaczyna przejawiać cechy autystyczne ${ }^{28}$. Badacz podkreśla, iż zachowania tego typu mogą pojawić się w rozwoju każdego dziecka jako mechanizm obronny przed doświadczanym lękiem i brakiem poczucia bezpieczeństwa w relacji z matką ${ }^{29}$. Zgodnie z omawianą koncepcją zaburzenia spektrum autyzmu rozwijają się pod wpływem wystąpienia kilku czynników: podatności na zranienie, która powoduje obniżenie odporności dziecka na czynniki zewnętrzne o charakterze patogennym, a także patogennych czynników zewnętrznych, do których zalicza: „brak bezpośredniego kontaktu cielesnego (samotne leżenie w łóżeczku), wielogodzinna rozłąka po porodzie, wspólne chwile matki i dziecka jedynie podczas sytuacji karmienia oraz awersyjne

\footnotetext{
26 Ibidem.

27 Ibidem, s. 352.

${ }^{28}$ L. Bobkowicz-Lewartowska, op. cit., s. 34.

${ }^{29}$ M. Talaroska, A. Florkowski, P. Gałecki, K. Zboralski, op. cit., s. 102.
} 
doznania, jak klaps w pośladek i szybkie odcięcie pępowiny po urodzeniu" ${ }^{30}$. Niko Tinbergen podkreśla również, iż duże znaczenie w etiologii zaburzeń spektrum autyzmu ma pęd cywilizacyjny, sprawiający iż matki mają coraz mniej czasu dla swoich dzieci, są zapracowane, przemęczone, nastawione na karierę zawodową, a także wykazują skłonności depresyjne. Stwarzane przez nie środowisko wychowawcze nie sprzyja zatem rozwojowi społecznemu dzieci ${ }^{31}$.

Koncepcja autorstwa Jiriny Prekop również wpisuje się w założenia psychoanalitycznego sposobu tłumaczenia przyczyn zaburzeń spektrum autyzmu. Badaczka uważa, iż powodem występowania specyficznych zachowań $\mathrm{u}$ dzieci $\mathrm{z}$ autyzmem jest zbyt statyczny tryb życia kobiet spodziewających się dziecka. Według autorki zachowania takie jak: kompulsje, stereotypie czy rytuały występujące $\mathrm{u}$ dzieci wynikają $\mathrm{z}$ niewystarczającej stymulacji trzech kanałów: westybularnego, kinestetycznego i dotykowego. Niezaspokojone $\mathrm{w}$ trakcie życia płodowego potrzeby powodują, iż dzieci starają się samodzielnie dostarczyć sobie brakujących im bodźców ${ }^{32}$.

Psychoanalityczne spojrzenie na etiologię zaburzeń spektrum autyzmu przedstawione $\mathrm{w}$ opisanych wyżej koncepcjach opiera się $\mathrm{w}$ znacznej mierze na wywiadach i rozmowach, często o charakterze retrospektywnym, dlatego też należy mieć na uwadze, iż mogą one być nieobiektywne ${ }^{33}$.

Cechą wspólną, charakterystyczną dla przedstawionych poglądów jest zbudowanie ich na założeniu, iż główną przyczyną wystąpienia autyzmu u dziecka jest nieprawidłowa relacja między niemowlęciem a matką 34 .

Akcentowane $\mathrm{w}$ omawianych teoriach cechy osobowości rodziców dzieci z autyzmem, do których zalicza się m.in.: chłód emocjonalny,

${ }^{30}$ L. Bobkowicz-Lewartowska, op. cit., s. 35.

${ }^{31}$ M. Młynarska, op. cit., s. 89.

32 Ibidem.

33 Ibidem.

${ }^{34}$ M. Talaroska, A. Florkowski, P. Gałecki, K. Zboralski, op. cit., s. 99. 
sztywność, pedanteria, przeintelektualizowanie, usilne dążenie do osiągania sukcesów zawodowych, niezdolność do okazywania uczuć, a także brak umiejętności rozumienia i zaspokajania potrzeb dziecka stanowią przyczynę wyizolowania dzieci, ich ucieczki we własny wewnętrzny świat, odgrodzony szklanym murem od świata zewnętrznego. Postrzeganie etiologii zaburzeń spektrum autyzmu $\mathrm{w}$ takich kategoriach spowodowało przypisanie matkom etykiety zimnych oraz obwinianie ich o zaburzenie występujące $\mathrm{u}$ dzieci. Wiązało się to z ich społecznym naznaczaniem, a także doświadczaniem przez nie przeciążenia psychicznego i emocjonalnego spowodowanego poczuciem winy. W rezultacie samopoczucie psychiczne matek przekładało się na funkcjonowanie poszczególnych członków rodziny oraz rodziny jako całości ${ }^{35}$.

Badania prowadzone od lat 70. XX w. nie potwierdzają hipotezy mówiącej o tym, by czynniki psychospołeczne odgrywały kluczową rolę $\mathrm{w}$ etiologii zaburzeń spektrum autyzmu ${ }^{36}$. Mimo to koncepcje psychoanalityczne również dzisiaj znajdują swoich zwolenników. Współcześni psychoanalitycy akcentują przeżytą przez dziecko traumę wynikającą z faktu, iż w trakcie jego rozwoju miała miejsce wyjątkowo trudna sytuacja. Zdaniem badaczy pojawiający się czynnik traumatyczny wywołuje u dziecka silny lęk, z którym stara się ono poradzić sobie w sposób jemu dostępny - głównie poprzez wycofanie z relacji społecznych i izolację. Trzeba również podkreślić, iż współcześnie czynników traumatycznych nie upatruje się w osobowości matek, lecz przypisuje się go sytuacjom mającym miejsce we wczesnych fazach rozwoju dziecka, w których jego podstawowe potrzeby zostały zdeprywowane. Do takich sytuacji zaliczyć można oddzielenie dziecka od matki zaraz po porodzie i umieszczenie go w klasycznym inkubatorze, będącym dla dziecka środowiskiem obcym i nieprzyjemnym, w którym nie czuje się ono

35 E. Pisula, D. Danielewicz, op. cit., s. 11; E. Pisula, Mate dziecko z autyzmem..., s. 22-23; E. Pisula, Autyzm. Przyczyny, symptomy, terapia..., s. 25; M. Suchowierska, P. Ostaszewski, P. Bąbel, op. cit., s. 28.

${ }^{36}$ M. Talaroska, A. Florkowski, P. Gałecki, K. Zboralski, op. cit., s. 102. 
bezpiecznie. Jednak również ta teoria, rozpatrywana w kategorii wiodącego czynnika wywołującego zaburzenia spektrum autyzmu nie uzyskała empirycznego potwierdzenia ${ }^{37}$.

\section{Czynniki środowiskowe}

Analizując etiologię zaburzeń spektrum autyzmu, nie można pominąć czynników natury środowiskowej. Rysunek 1. stanowi próbę uporządkowania elementów składających się na podgrupy wpisujące się z kolei w szeroką i zróżnicowaną grupę czynników środowiskowych. W celu dokładnego zrozumienia poruszanego tematu $\mathrm{w}$ niniejszej części pracy dokonano charakterystyki każdej z wyodrębnionych podgrup.

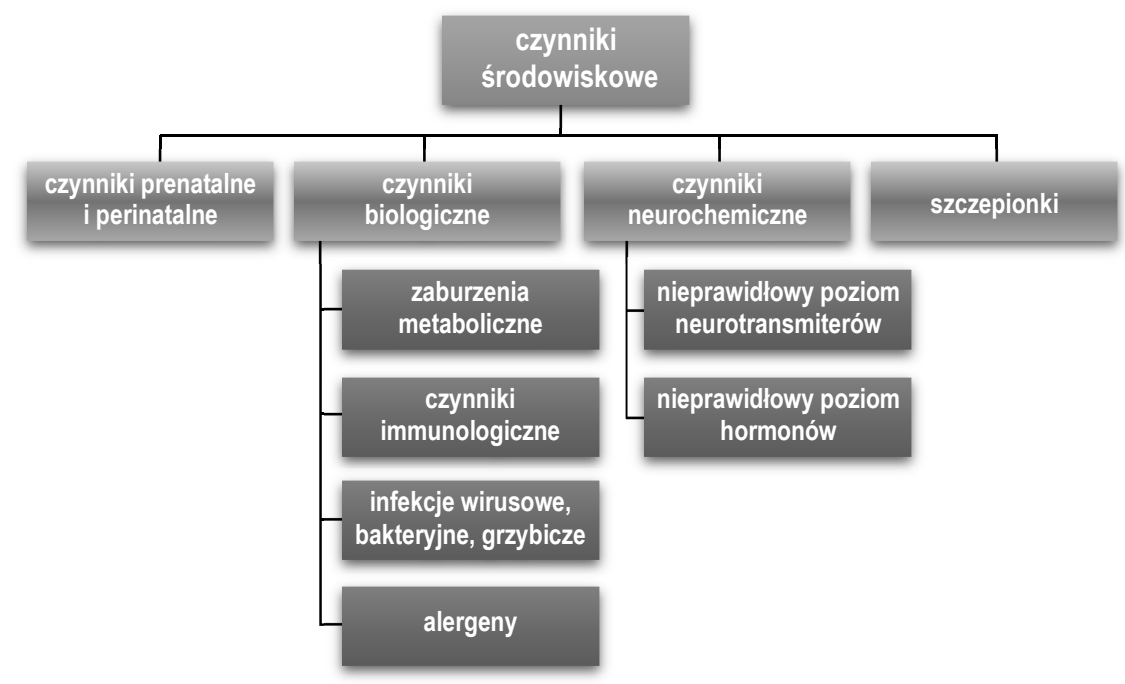

Rys. 1. Środowiskowe czynniki ryzyka zaburzeń spektrum autyzmu Źródło: opracowanie własne ${ }^{38}$

${ }^{37}$ Ibidem.

${ }^{38}$ Na podstawie: U. Frith, Autyzm. Wyjaśnienie tajemnicy, Gdańskie Wydawnictwo Psychologiczne, Sopot 2008; E. Pisula, Autyzm...; B. Winczura, Dziecko z autyzmem... 


\section{Czynniki prenatalne i perinatalne}

Badania prowadzone nad etiologią zaburzeń spektrum autyzmu donoszą, iż zdarza się, że już w okresie życia płodowego, a także podczas porodu, występują pewne czynniki, które w konsekwencji mogą zwiększać ryzyko pojawienia się zaburzeń rozwoju małego dziecka ${ }^{39}$.

Naukowcy dostrzegają zagrożenie w takich czynnikach jak: wiek rodziców (matki powyżej 30 r.ż., ojcowie powyżej 35 r.ż.), krwawienia w czasie ciąży - zwłaszcza w pierwszym lub drugim trymestrze, przyjmowanie leków przez matkę podczas ciąży, a także: poród pośladkowy lub z użyciem narzędzi, niska waga urodzeniowa (równa bądź niższa niż 2500 g), wcześniactwo, a także przenoszenie ciąży ${ }^{40}$.

Według niektórych badaczy nie bez znaczenia dla rozwoju dziecka pozostają również: cukrzyca ciążowa, sztuczne wywoływanie porodu, cesarskie cięcie, zatrucie ciążowe oraz kolejność urodzeń dzieci - szczególnie zagrożone wystąpieniem zaburzeń spektrum autyzmu są dzieci z pierwszej, trzeciej lub dalszej ciąży41.

Gabriela Jagielska ${ }^{42}$ do czynników ryzyka pre- i perinatalnego zalicza ponadto:

- zagrożenie poronieniem,

- niedotlenienie płodu,

- wady wrodzone,

- codzienne palenie papierosów przez matkę podczas ciąży,

- smółkę w wodach płodowych (tzw. zielone wody płodowe).

Stres prenatalny stanowi kolejny czynnik mogący niekorzystnie wpłynąć na wczesny rozwój mózgu dziecka. Wyniki jednych z badań ${ }^{43}$ ukazują, iż matki dzieci z autyzmem przeżywały szczególnie

${ }^{39}$ Ibidem, s. 355

${ }^{40}$ A. Wojciechowska, op. cit., s. 320.

${ }^{41}$ E. Pisula, Mate dziecko z autyzmem..., s. 23; E. Pisula, Autyzm..., s. 66.

${ }^{42}$ G. Jagielska, Etiologia zaburzeń autystycznych, [w:] Autyzm i zespót Aspergera, red. J. Komander, G. Jagielska, A. Bryńska, Wydawnictwo lekarskie PZWL, Warszawa 2009, s. 24.

43 Za: P. Gołaska, Etiologia zaburzeń ze spektrum autyzmu. Przegląd wybranych koncepcji, „Psychiatria i psychologia kliniczna” 2013, nr 1. 
silny stres między 21. a 32. tygodniem ciąży ${ }^{44}$. Okazało się, iż właśnie $\mathrm{w}$ tym czasie powstają nieprawidłowości $\mathrm{w}$ strukturach i funkcjonowaniu mózgu osób z zaburzeniami spektrum autyzmu. Marleen Claassen tłumaczy zachodzące zjawisko w następujący sposób: przeżywany przez matkę stres wpływa na podniesienie poziomu leukocytów oraz glikokortykoidów u dziecka, które z kolei prowadzą do zaburzenia rozwoju jego struktur mózgowych. Można zatem stwierdzić, iż traktowanie sytuacji stresujących, doświadczanych przez matkę właśnie $w$ tym okresie ciąży, jako czynnika zagrażającego prawidłowemu rozwojowi dziecka, nie jest bezpodstawne. Należy jednak pamiętać, iż z całą pewnością nie jest to czynnik izolowany ${ }^{45}$.

Simon Baron - Cohen i Patrick Bolton są zdania, iż czynniki pochodzące $z$ tej grupy „są ewidentne jedynie u mniejszości dzieci $\mathrm{z}$ autyzmem oraz, że występują one również u dzieci, które rozwijają się absolutnie prawidłowo. Toteż, czynniki te same w sobie nie muszą powodować autyzmu, lecz mogą mieć pewien $u d z i a t$ w powstawaniu autyzmu u niektórych dzieci" 46 . Uta Frith ${ }^{47}$ dodaje, iż: „trudny poród może być przyczyną wielu różnych problemów rozwojowych i nie jest w jakiś szczególny sposób związany z autyzmem".

\section{Czynniki biologiczne}

Zaburzenia spektrum autyzmu łączą się z problemami zdrowotnymi, do których zaliczyć można: zaburzenia metaboliczne, obniżenie odporności, występowanie infekcji wirusowych, grzybiczych, bakteryjnych oraz alergie ${ }^{48}$.

U osób z zaburzeniami spektrum autyzmu częściej niż przeciętnie występuje zaburzenie metabolizmu puryn (adeniny i guaniny).

${ }^{44}$ P. Gołaska, op. cit., s. 10.

${ }^{45}$ E. Pisula, Autyzm..., s. 67.

${ }^{46}$ S. Baron-Cohen, P. Bolton, Autyzm. Fakty, Wydawnictwo JAK, Kraków 1999, s. 35 .

47 U. Frith, Autyzm..., s. 99.

48 E. Pisula, Autyzm..., s. 68. 
„Badania biochemiczne wykazały zwiększoną przemianę białkową u dzieci autystycznych i wydalanie puryn z moczem" 49 . Natomiast wysoki poziom peptydów $\mathrm{w}$ organizmach osób $\mathrm{z}$ zaburzeniami spektrum autyzmu zauważył Karl Reichelt ${ }^{50}$. Zdaniem badacza u tej grupy osób może dochodzić do swoistego przesycenia niektórymi peptydami ${ }^{51}$.

Okazało się, że nieprawidłowe związki chemiczne, które Reichelt regularnie wykrywał w próbkach moczu, należą do tej samej grupy substancji, co heroina. Ponieważ wiele innych fizycznych objawów, które odkrywał, przypominało objawy występujące po użyciu lub nadużyciu heroiny albo morfiny, wysunął hipotezę, że jeśli dane produkty zostaną usunięte $\mathrm{z}$ diety, spowoduje to złagodzenie objawów ${ }^{52}$.

Jedną z najbardziej charakterystycznych chorób metabolicznych, która nieleczona, doprowadza do wystąpienia u dziecka autystycznych symptomów jest fenyloketonuria. Do objawów tych zaliczyć można m.in.: stereotypie ruchowe, niezborność ruchową, chód atetotyczny, nadpobudliwość ruchową, zaburzenia mowy, napady złości oraz agresji i autoagresji, a także występowanie problemów ze snem, obniżenie zdolności koncentrowania uwagi, lęk przed nieznanymi ludźmi oraz zmianami $\mathrm{w}$ otoczeniu ${ }^{53}$. Przyczyną fenyloketonurii jest nieprawidłowy metabolizm fenyloalaniny. Wczesne zastosowanie diety eliminacyjnej chroni ośrodkowy układ nerwowy przez uszkodzeniem, dzięki czemu dziecko ma szansę rozwijać się prawidłowo ${ }^{54}$.

Badania wskazują, iż między deficytami immunologicznymi i nasileniem autystycznych objawów zachodzi korelacja. Taki stan

${ }^{49}$ M. Młynarska, op. cit., s. 91.

50 A. Wojciechowska, op. cit., s. 320.

${ }^{51}$ L. Bobkowicz-Lewartowska, op. cit., s. 43.

${ }^{52}$ R. Kessick, Autyzm i dieta. O czym warto wiedzieć, Fraszka Edukacyjna, Warszawa 2010, s. 13.

${ }^{53}$ K. Mowszet, T. Hutyra, Dziecko z fenyloketonuria, [w:] Dzieci chore, niepetnosprawne $i$ z utrudnieniami w rozwoju, red. B. Cytowska, B. Winczura, A. Stawarski, Oficyna Wydawnicza „Impuls”, Kraków 2008, s. 204.

54 G. Jagielska, op. cit., s. 22. 
jest rezultatem rozregulowania systemu odporności dzieci już od najmłodszych lat życia ${ }^{55}$.

Naukowcy dostrzegają czynniki ryzyka również w zakażeniach grzybiczych - głównie wiązanych z Candida albicans oraz wirusowych. U. Frith ${ }^{56}$ uważa, iż "choroby wirusowe rozwijają się gwałtownie i mogą zainfekować ośrodkowy układ nerwowy, doprowadzając do trwałego uszkodzenia mózgu. W rzadkich przypadkach zakażenie ośrodkowego układu nerwowego w krytycznym okresie przed porodem lub po porodzie może doprowadzić do autyzmu". Wirusy, które zgodnie z hipotezami mogą przyczyniać się do występowania zaburzeń spektrum autyzmu u dzieci, to:

- retrowirus,

- wirus różyczki,

- wirus cytomegalii,

- opryszczkowe zapalenie mózgu ${ }^{57}$.

Coraz częściej w etiologii zaburzeń spektrum autyzmu dostrzega się znaczenie różnych alergii. Przyczyną wystąpienia reakcji alergicznych mogą być zarówno produkty żywnościowe, jak i alergeny wziewne, w tym pyłki traw i roztocza ${ }^{58}$. Bernard Rimland jest zdania, iż niektóre produkty spożywcze mogą wywoływać reakcje alergiczne w układzie nerwowym dziecka ${ }^{59}$. Do produktów tych zalicza: „pszenicę (mąkę), mleko, cukier, sól, barwniki sztuczne, aromaty i niektóre sztuczne przyprawy"60. Naukowcy twierdzą, iż u osób z zaburzeniami spektrum autyzmu dość często występuje nadwrażliwość na gluten i kazeinę. Obecność tych substancji w organizmie powoduje wywołanie reakcji alergicznej, skutkującej wzmożeniem autystycznych symptomów ${ }^{61}$. Pamiętać jednak należy, iż między zaburzeniami

55 E. Pisula, Autyzm..., s. 70.

56 U. Frith, op. cit., s. 99.

57 S. Baron-Cohen, P. Bolton, op. cit., s. 35-36; U. Frith, op. cit., s. 99.

58 L. Bobkowicz-Lewartowska, op. cit., s. 43; B. Winczura, Dziecko z autyzmem..., s. 355 .

${ }^{59}$ A. Wojciechowska, op. cit., s. 320.

${ }^{60}$ M. Młynarska, op. cit., s. 91-92.

${ }^{61}$ R. Kessick, Autyzm i dieta. O czym warto wiedzieć, Fraszka Edukacyjna, Warszawa 2010, s. 17 
natury biologicznej (zwłaszcza metabolicznej) a występowaniem autyzmu u dziecka nie ma znaku równości, zatem każdą z powyższych hipotez należy sprawdzić u odpowiednich specjalistów.

\section{Czynniki neurochemiczne}

Neuroprzekaźniki odgrywają istotną rolę w procesach pobudzęnia i hamowania układu nerwowego. Nieprawidłowości w funkcjonowania systemu neuroprzekaźnictwa mogą w rezultacie doprowadzić do zaburzeń natury neurologicznej, psychicznej, a także do wystąpienia deficytów neuropsychologicznych ${ }^{62}$. W tabeli 2. przedstawiono neuroprzekaźniki, których nieprawidłowe funkcjonowanie może mieć znaczenie w etiologii zaburzeń spektrum autyzmu.

Tabela 2. Nieprawidłowości w funkcjonowaniu neurotransmiterów istotne w etiologii zaburzeń spektrum autyzmu

\begin{tabular}{|l|l|l|}
\hline \multicolumn{1}{|c|}{$\begin{array}{c}\text { Nazwa } \\
\text { neurotransmitera }\end{array}$} & \multicolumn{1}{|c|}{ Obszar nieprawidłowości } & \multicolumn{1}{c|}{ Konsekwencje dla osób z ASD } \\
\hline $\begin{array}{l}\text { Zaburzenia serotoni- } \\
\text { nergicznego systemu } \\
\text { przekaźnictwa }\end{array}$ & $\begin{array}{l}\text { Zwiększony poziom serotoniny } \\
\text { w surowicy i płytkach krwi } \\
\text { Anderson (2002) }\end{array}$ & $\begin{array}{l}\text { Zaburzony kontakt z matką, trud- } \\
\text { ność z wchodzeniem w interakcje } \\
\text { społeczne, reagowanie nadmierną } \\
\text { agresją na pojawiające się bodźce } \\
\text { McNamara (2008) - badania na } \\
\text { modelu zwierzęcym }\end{array}$ \\
\cline { 2 - 3 } & $\begin{array}{l}\text { Podwyższony poziom serotoniny } \\
\text { w ośrodkowym układzie nerwo- } \\
\text { wym } \\
\text { Okado (2001) }\end{array}$ & $\begin{array}{l}\text { Zaburzenia w interakcjach spo- } \\
\text { łecznych, stereotypie ruchowe i za- } \\
\text { burzenia percepcji } \\
\text { Boylan (2007) - badania na mode- } \\
\text { lu zwierzęcym }\end{array}$ \\
\cline { 2 - 3 } & $\begin{array}{l}\text { Mniejsze zagęszczenie receptorów } \\
5 \text { HT2 w korze mózgowej, dotyczą- } \\
\text { ce następujących obszarów: zakrętu } \\
\text { obręczy, płata czołowego w oby- } \\
\text { dwu półkulach, górnej części płata }\end{array}$ & $\begin{array}{l}\text { Problemy z uwagą, pamięcią do- } \\
\text { wolną, myśleniem, kontrolą } \\
\text { emocji } \\
\text { Murphy (2006) }\end{array}$ \\
\hline
\end{tabular}

${ }^{62}$ R. Wujcik, A. Porzycka, A. Witusik, T. Pietras, Neurorozwojowa hipoteza autyzmu, [w:] Autyzm - epidemiologia, diagnoza i terapia, red. T. Pietras, A. Witusik, P. Gałecki, Wydawnictwo Continuo, Wrocław 2010, s. 41. 
cd. tab. 2

\begin{tabular}{|c|c|c|}
\hline $\begin{array}{c}\text { Nazwa } \\
\text { neurotransmitera }\end{array}$ & Obszar nieprawidłowości & Konsekwencje dla osób z ASD \\
\hline & $\begin{array}{l}\text { skroniowego w obydwu półkulach, } \\
\text { lewego płata ciemieniowego } \\
\text { Murphy (2006) }\end{array}$ & \\
\hline \multirow[t]{3}{*}{$\begin{array}{l}\text { Zaburzenia GABA-er- } \\
\text { gicznego i glutaminer- } \\
\text { gicznego systemu } \\
\text { przekaźnictwa }\end{array}$} & $\begin{array}{l}\text { Niedobór komórek Purkinjego po- } \\
\text { wiązanych z GABA-ergicznymi in- } \\
\text { terneuronami } \\
\text { Amaral (2008) }\end{array}$ & $\begin{array}{l}\text { Zaburzenia połączeń móżdżku } \\
\text { z korowymi ośrodkami, które } \\
\text { odpowiadają za funkcje moto- } \\
\text { ryczne i poznawcze } \\
\text { Amaral (2008) }\end{array}$ \\
\hline & $\begin{array}{l}\text { Nieprawidłowy poziom białka de- } \\
\text { karboksylazy glutaminianu (GAD67) } \\
\text { w interneuronach drobnocząstecz- } \\
\text { kowej warstwy kory mózgu } \\
\text { Yip }(2007,2008)\end{array}$ & $\begin{array}{l}\text { Wystąpienie klinicznych cech au- } \\
\text { tyzmu } \\
\text { Yip }(2007,2008)\end{array}$ \\
\hline & $\begin{array}{l}\text { Podwyższenie stężenia kwasu } \\
\text { glutaminowego w stężeniu krwi } \\
\text { Moreno-Fuenmayor (1996) }\end{array}$ & $\begin{array}{l}\text { Zaburzenia związane z uczeniem } \\
\text { się, pamięcią, a także motywacją } \\
\text { Moreno-Fuenmayor (1996) }\end{array}$ \\
\hline $\begin{array}{l}\text { Zaburzenia neuroprze- } \\
\text { kaźnictwa za pośred- } \\
\text { nictwem katecholamin }\end{array}$ & $\begin{array}{l}\text { Podwyższony poziom dopaminy } \\
\text { w korze czołowej } \\
\text { Narita (2002) }\end{array}$ & $\begin{array}{l}\text { Uszkodzenie dopaminowych } \\
\text { neuronów, skutkujących rozwi- } \\
\text { nięciem się autyzmu } \\
\text { Wierzbiński (2005) - badania na } \\
\text { modelu zwierzęcym }\end{array}$ \\
\hline \multirow[t]{4}{*}{$\begin{array}{l}\text { Zaburzenia neuroprze- } \\
\text { kaźnictwa z udziałem } \\
\text { neuropeptydów }\end{array}$} & $\begin{array}{l}\text { Większe stężenie endorfin w płynie } \\
\text { mózgowo-rdzeniowym } \\
\text { Gilberg (1995), Van Ree (2000) }\end{array}$ & $\begin{array}{l}\text { Obniżenie wrażliwości na ból - } \\
\text { wystąpienie autoagresji } \\
\text { Gilberg (1995), Van Ree (2000) }\end{array}$ \\
\hline & $\begin{array}{l}\text { Wyższe stężenie wazoaktywnego } \\
\text { peptydu jelitowego } \\
\text { Nelson (2001) }\end{array}$ & $\begin{array}{l}\text { Zaburzenia snu i dolegliwości ze } \\
\text { strony przewodu pokarmowego } \\
\text { Lam (1992) }\end{array}$ \\
\hline & $\begin{array}{l}\text { Mniejsze stężenie oksytocyny } \\
\text { w surowicy krwi } \\
\text { Hollander (2003) }\end{array}$ & $\begin{array}{l}\text { Występowanie stereotypii rucho- } \\
\text { wych } \\
\text { Hollander (2003) } \\
\text { Zaburzenia związane z kształto- } \\
\text { waniem pamięci społecznej } \\
\text { Crawley (2007) }\end{array}$ \\
\hline & $\begin{array}{l}\text { Zaburzenia ośrodkowego neuroprze- } \\
\text { kaźnictwa z udziałem wazopresyny } \\
\text { Hammock (2006) }\end{array}$ & $\begin{array}{l}\text { Trudności w kształtowaniu więzi } \\
\text { społecznych } \\
\text { Hammock (2006) }\end{array}$ \\
\hline
\end{tabular}

Źródło: opracowanie własne ${ }^{63}$

${ }^{63}$ Na podstawie: R. Wujcik, A. Porzycka, A. Witusik, T. Pietras, Neurorozwojowa hipoteza autyzmu, [w:] Autyzm - epidemiologia, diagnoza i terapia, red. T. Pietras, A. Witusik, P. Gałecki, Wydawnictwo Continuo, Wrocław 2010, s. 41-47. 
Badacze dostrzegli ponadto związek między występowaniem zachowań charakterystycznych dla zaburzeń spektrum autyzmu a poziomem testosteronu danej osoby. Hormon ten bierze udział w rozwoju niektórych struktur mózgowych, m.in.: kory nowej, hipokampa i układu limbicznego. Wymienione obszary są odpowiedzialne za pewne cechy zachowania, powiązane z płcią: agresywność, poziom aktywności oraz orientację przestrzenną ${ }^{64}$.

Naukowcy wyodrębniają trzy okresy nagłego wzrostu testosteronu w organizmie:

- od 8. do 24. tygodnia ciąży - testosteron płodowy,

- od narodzin do ok. 4. do 6. miesiąca życia - testosteron noworodkowy,

- okres adolescencji65.

Hipoteza testosteronowa powstała w oparciu o wyniki różnych badań. Polega ona na przekonaniu, iż istnieje związek między poziomem owego hormonu występującym w życiu płodowym a umiejętnością nawiązywania interakcji społecznych u dzieci w wieku czterech lat ${ }^{66}$. Ponadto zauważono, że wysoki poziom testosteronu płodowego u chłopców wiąże się z występowaniem u nich wąskich i uporczywych zainteresowań ${ }^{67}$. Badania potwierdzające ową hipotezę donoszą, że osoby z wysokim poziomem testosteronu $\mathrm{w}$ życiu płodowym preferują obiekty nieożywione - osoby z zaburzeniami spektrum autyzmu cechuje ponadprzeciętne zainteresowanie przedmiotami mechanicznymi ${ }^{68}$. Można zatem wnioskować, iż nie jest wykluczone, że wysoki poziom testosteronu płodowego ma znaczenie w etiologii zaburzeń $\mathrm{z}$ autystycznego spektrum ${ }^{69}$.

Rolę innego hormonu, poprzez swoje badania, odkryli: Edward Ritvo w badaniach z 1993 r., a także: Melke, Goubran Botros, Cha-

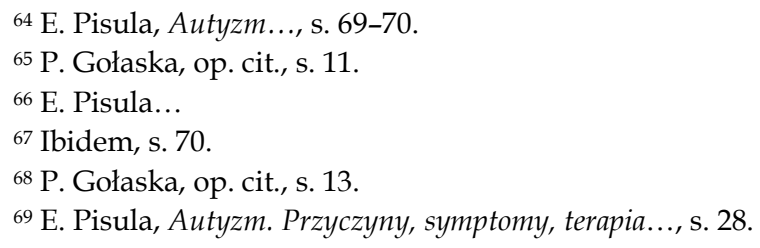


ste, Betancur, Nygren i inni w publikacji z roku 200870. Dostrzegają oni nieprawidłowości w okołodobowym rytmie wydzielania melatoniny występujące u osób z zaburzeniami spektrum autyzmu. Naukowcom nie udało się do tej pory ustalić przyczyn tego stanu. Jednak bez wątpienia deficyt tego hormonu stanowi źródło problemów ze snem, z którymi borykają się osoby z autyzmem¹.

\section{Szczepionki}

W toku poszukiwań czynników wpływających na występowanie zaburzeń spektrum autyzmu w 1998 r. Andrew Wakefield zwrócił uwagę na zbieżność występującą między czasem podania potrójnej szczepionki przeciwko śwince, odrze i różyczce (MMR) a regresem $w$ rozwoju i/lub pojawieniem się autystycznych symptomów u dziecka72.

W szczepionce tej znajduje się thimerosal - substancja zawierająca rtęć.

Pojawiło się przypuszczenie, że w przypadku niektórych osób zaburzenia $\mathrm{z}$ autystycznego spektrum powstają prawdopodobnie w wyniku kombinacji czynników genetycznych i biochemicznych, które znacznie obniżają zdolność usuwania rtęci z organizmu ${ }^{73}$.

Zdaniem niektórych badaczy taka sytuacja może zwiększyć ryzyko wystąpienia zaburzeń spektrum autyzmu u dziecka. Z kolei badania epidemiologiczne dotyczące częstotliwości występowania autyzmu u dzieci przed i po wprowadzeniu powszechnych szczepień z użyciem potrójnej szczepionki wykluczają taki związek $^{74}$.

70 E. Pisula, Autyzm..., s. 71.

${ }^{71}$ L. Bobkowicz-Lewartowska, op. cit., s. 43; E. Pisula, Autyzm..., s. 71; R. Wujcik, A. Porzycka, T. Witusik, op. cit., s. 48.

72 G. Jagielska, op. cit., s. 25; E. Pisula, Autyzm..., s. 27.

73 Ibidem, s. 69.

${ }^{74}$ G. Jagielska, op. cit., s. 25. 
Światowa Organizacja Zdrowia podaje, że nie można jednoznacznie stwierdzić, iż szczepionka MMR prowadzi do wystąpienia zaburzeń z autystycznego spektrum. Nie ma dowodów, jakoby mogła stanowić jedyny czynnik wywołujący owe zaburzenie. Istnieje jednak prawdopodobieństwo, iż w przypadku niektórych dzieci może zwiększyć ryzyko ujawnienia się bądź nasilenia autystycznych $\operatorname{cech}^{75}$.

Opisane czynniki pochodzenia środowiskowego mogą stanowić zagrożenie dla prawidłowego rozwoju dziecka. Należy jednak pamiętać, iż etiologia autyzmu jest złożona, dlatego też czynniki natury środowiskowej, genetycznej czy neurologicznej, zazwyczaj występują razem, w różnorodnej kompilacji.

\section{Czynniki genetyczne}

Kolejnym obszarem zagadnień $\mathrm{w}$ etiologii zaburzeń spektrum autyzmu są czynniki genetyczne. W celu zweryfikowania hipotezy dotyczącej ich znaczenia, przeprowadzono liczne badania ${ }^{76}$.

Pierwsza praca, w której ukazano związek pomiędzy uwarunkowaniami genetycznymi a zachowaniami autystycznymi, pochodzi z 1977 r. Jej autorami są Susan Folstein i Michael Rutter. Dokonali oni opisu 11 par bliźniąt monozygotycznych i 10 par bliźniąt dizygotycznych. $W$ każdej z par przynajmniej u jednego dziecka zdiagnozowano autyzm. Wyniki badań wykazały, iż występowanie autyzmu u obojga rodzeństwa $\mathrm{w}$ populacji bliźniąt monozygotycznych szacuje się na $36 \%$, natomiast $\mathrm{w}$ grupie bliźniąt dizygotycznych bliskie było zeru ${ }^{77}$. Częstsze współwystępowanie zaburzeń spektrum autyzmu wśród bliźniąt o takim samym materiale gene-

75 U. Frith, op. cit., s. 102; E. Pisula, Autyzm..., s. 69.

76 S. Baron-Cohen, P. Bolton, op. cit., s. 31.

77 E. Pisula, Autyzm..., s. 58. 
tycznym, ukierunkowuje zatem myślenie badaczy na ważność czynników genetycznych $w$ etiologii zaburzeń $\mathrm{z}$ kręgu autyzmu. Uta Frith ${ }^{78}$ zwraca uwagę, iż „wielu z braci par niezgodnych cierpiało $\mathrm{w}$ istocie na łagodniejszą postać zaburzenia autystycznego, spełniając bardziej współczesne, szersze kryteria". Stwierdzenie to jest niezwykle istotne, ponieważ stosując podczas badań właśnie tzw. szersze kryteria, współwystępowanie zaburzeń spektrum autyzmu u bliźniąt monozygotycznych wynosi $90 \%{ }^{79}$. Z kolei wyniki późniejszych badań wykazują, że częstotliwość współwystępowania autyzmu u bliźniąt monozygotycznych określa się na 69-89\%, natomiast $\mathrm{w}$ przypadku bliźniąt dizygotycznych to $6-8 \% 80$. Gabriela Jagielska ${ }^{81}$ podaje natomiast, iż "analiza występowania u bliźniąt objawów szerszego spektrum autystycznego (zaburzenia komunikacji, zaburzenia funkcjonowania społecznego) wykazała jeszcze większą zgodność, wynoszącą 92\% u bliźniąt jednojajowych i 10\% u dwujajowych". Choć wyniki procentowe, z przedstawionych badań są rozbieżne, to każde $\mathrm{z}$ nich wskazuje na zdecydowanie częstsze współwystępowanie zaburzeń spektrum autyzmu $\mathrm{w}$ grupie bliźniąt monozygotycznych, niż w grupie bliźniąt dizygotycznych czy też w populacji ogólnej.

Badania dowodzą również, iż zaburzenia spektrum autyzmu częściej występują u rodzeństwa dzieci z autyzmem niż w populacji ogólnej82.

Ryzyko wystąpienia tego zaburzenia u kolejnego dziecka, mimo że obiektywnie stosunkowo niewielkie (wynosi 2-8\%), jednak zwiększa się ok. 50-200 razy w przypadku rodzin posiadających wcześniej dziecko z zaburzeniami spektrum autyzmu, w stosunku do rodzin, które takich dzieci nie posiadały ${ }^{83}$.

\footnotetext{
78 U. Frith, op. cit., s. 97.

79 Ibidem.

80 Za: E. Pisula, Małe dziecko z autyzmem..., s. 25.

${ }^{81}$ G. Jagielska, op. cit., s. 19-20.

82 B. Winczura, Dziecko z autyzmem..., s. 353.

83 E. Pisula, Autyzm. Przyczyny, symptomy, terapia..., s. 31.
} 
Ponadto u krewnych osób z zaburzeniami spektrum autyzmu zdecydowanie częściej obserwuje się występowanie cech, wpisujących się w triadę zaburzeń autystycznych. Specyficzne zachowania, choć typowe, mają jednak zbyt małe nasilenie, by móc zdiagnozować u danej osoby zaburzenia spektrum autyzmu, dlatego też określa się je jako: lżejszy wariant autyzmu lub też szerszy fenotyp autyzmu. Do jego charakterystycznych cech Dawson ze współpracownikami zaliczają:

- trudności $w$ przetwarzaniu informacji dotyczących twarzy (np. w rozpoznawaniu emocji),

- obniżona zdolność tworzenia więzi społecznych lub wrażliwość na wzmocnienia społeczne,

- gorzej rozwinięta zdolność naśladowania ruchów,

- słabsza pamięć bodźców społecznych,

- zaburzenia funkcji wykonawczych (trudności związane z planowaniem, kontrolą wykonania oraz płynnością działania),

- gorzej rozwinięte zdolności językowe ${ }^{84}$.

Należy jednak podkreślić, iż badania prowadzone nad fenotypem krewnych osób z zaburzeniami spektrum autyzmu nie są jednoznaczne, a przy ich analizie trzeba mieć na uwadze wiele zmiennych ${ }^{85}$.

Kwestie związane z rolą genetyki w zaburzeniach spektrum autyzmu stanowią kolejny temat dyskusji badaczy. Do tej pory nie udało się ustalić żadnego genu odpowiedzialnego za występowanie autyzmu. Mało prawdopodobne jest jednak, by zaburzenie o tak szerokim zróżnicowaniu objawów i stopniu nasilenia cech, mogło być spowodowane nieprawidłowością pojedynczego genu ${ }^{86}$. Obecnie przypuszcza się, iż za powstanie autyzmu odpowiedzialnych jest kilka genów (od 2 do 10-15), z wieloma ich lokalizacjami, m.in.: 4p12, 5q34-35, 6q15, 15q12 (Ma i in. - publikacja z 2005 r. ${ }^{87}$ ), 1q41-42

${ }^{84}$ E. Pisula, Autyzm..., s. 59.

85 E. Pisula, Autyzm..., s. 64.

${ }^{86}$ J. Hauser, M. Dmitrzak-Węglarz, Leksykon genetyki w psychiatrii, Termedia Wydawnictwo Medyczne, Poznań 2010, s. 17.

87 Za: R. Wujcik, A. Porzycka, A. Witusik, T. Pietras, op. cit. 
(Maussion i in., publikacja z $2008 \mathrm{r} .{ }^{88}$ ), a także 7q21.2 q36.2, 16p12.1 p13.3, 6q14.3 q23.2, 2q24.1 q33.1, 17q11.1 q21.2, 1q21 q44, 3q21.3 q29 (Yang i in. z 2007 r. ${ }^{89}$ ).

Wśród najczęstszych nieprawidłowości genetycznych występujących u osób z zaburzeniami spektrum autyzmu wymienia się:

- 15q11-13 - duplikacja części chromosomu 15,

- delecja 2q37,

- anomalie strukturalne chromosomu 7,

- nieprawidłowości w zakresie liczby i struktury chromosomów płciowych ${ }^{90}$.

Warto zaznaczyć, iż duplikacja 15q11-13 stanowi przyczynę wystąpienia zespołu Angelmana i zespołu Pradera-Williego. W obraz cech klinicznych obu tych zespołów wpisane są zachowania autystyczne ${ }^{91}$. Nie są to jednak przypadki odosobnione. Ze względu na fakt, iż jak wspomniano wcześniej, zaburzenia spektrum autyzmu łączą się $\mathrm{z}$ występowaniem nieprawidłowości $\mathrm{w}$ wielu genach, u osób z zaburzeniami genetycznymi, których przyczyna tkwi $\mathrm{w}$ nieprawidłowościach chromosomalnych, często stwierdza się występowanie cech charakterystycznych dla osób z autyzmem ${ }^{92}$. Do takich zaburzeń należą: zespół łamliwego chromosomu X, stwardnienie guzowate, nerwiakowłókniakowatość, fenyloketonuria, zespół Klinefeltera, zespół Angelmana, zespół Downa, zespół Pradera-Williego, zespół Smitha-Magenisa, zespół Williamsa, zespół Cornelii de Lange, zespół Noonana, zespół Coffina Sirisa, zespół Moebiusa, zespół Smitha-Lemliego-Opitza ${ }^{93}$. U osób z wszystkimi wymienionymi zespołami genetycznymi $\mathrm{z}$ mniejszym lub więk-

${ }^{88}$ Ibidem.

${ }^{89}$ Ibidem.

${ }^{90}$ E. Pisula, Autyzm..., s. 65.

${ }^{91}$ J. Błeszyński, Przegląd badań genetycznych koncepcji etiologii autyzmu, [w:] Szkoła Specjalna, nr 3, 2007, s. 178.

${ }^{92}$ E. Pisula, Autyzm..., ibidem.

${ }_{93}$ S. Baron-Cohen, P. Bolton, op. cit., s. 31-34; G. Jagielska, op. cit., s. 21; E. Pisula, Autyzm..., ibidem. 
szym nasileniem, pojawiają się takie nieprawidłowości jak: „opóźniony rozwój mowy, stereotypie ruchowe, zaburzenie koordynacji ruchowej, izolacja społeczna"94.

Czynniki genetyczne ciągle jeszcze wymagają głębszego poznania. Bez wątpienia jednak $\mathrm{w}$ niektórych przypadkach mogą odgrywać rolę $\mathrm{w}$ etiologii zaburzeń spektrum autyzmu. Mimo to, podobnie jak przy innych rodzajach czynników, pojawienie się samodzielnego, wyizolowanego czynnika genetycznego nie wystarczy, by u danej osoby wystąpiły symptomy pozwalające zdiagnozować zaburzenia spektrum autyzmu. Współcześnie coraz częściej wskazuje się na znaczenie nieprawidłowości neurologicznych, które mogą mieć istotny wpływ na występowanie zaburzeń z autystycznego spektrum.

\section{Czynniki neurologiczne}

Współcześnie coraz większe znaczenie $\mathrm{w}$ etiologii zaburzeń spektrum autyzmu przypisuje się czynnikom pochodzenia neurologicznego. U znacznej części osób z ASD występuje uszkodzenie mózgu, którego zakres i rozległość jest różna u poszczególnych osób ${ }^{95}$.

Populacja osób z zaburzeniami spektrum autyzmu jest bardzo zróżnicowana zarówno pod względem rodzaju oraz natężenia objawów, jak również sposobu funkcjonowania, dlatego też niemożliwym jest ustalenie jednoznacznych, występujących u wszystkich osób, przyczyn zaistniałego stanu rzeczy. Jednak badania poczynione $w$ tym temacie pozwoliły na sformułowanie pewnych hipotez dotyczących umiejscowienia nieprawidłowości w określonych obszarach mózgu ${ }^{96}$. Hipotezy te wraz z ich dokładnym opisem przedstawiono poniżej.

94 J. Błeszyński, op. cit.

${ }_{95}$ B. Winczura, Jak funkcjonuje mózg dzieci..., s. 285.

${ }^{96}$ E. Pisula, Autyzm..., s. 71. 
Tabela 3. Uszkodzone obszary mózgu u osób z zaburzeniami spektrum autyzmu hipotezy

\begin{tabular}{|c|c|}
\hline \multicolumn{2}{|l|}{ A. Płaty czołowe } \\
\hline \multicolumn{2}{|c|}{$\begin{array}{l}\text { Hipoteza: Uszkodzenie płatów czołowych } \\
\text { Autorzy badań: Giedd, Shaw, Wallace, Gogtay, Lenroot - } 2006\end{array}$} \\
\hline Funkcja sprawowana przez obszar: & $\begin{array}{c}\begin{array}{c}\text { Konsekwencje uszkodzenia obszaru } \\
\text { u osób z ASD: }\end{array} \\
\end{array}$ \\
\hline $\begin{array}{l}\text { - odpowiadają za funkcje ruchowe, a także } \\
\text { za pamięć wyuczonych działań ruchowych; } \\
\text { - odpowiada za planowanie i inicjowanie } \\
\text { działania w odpowiedzi na zdarzenia ze- } \\
\text { wnętrzne; } \\
\text { - umożliwia ocenę sytuacji i przewidywanie } \\
\text { konsekwencji zachowań; } \\
\text { - odpowiada za ekspresję językową oraz } \\
\text { mowę; } \\
\text { - umożliwia podejmowanie decyzji }\end{array}$ & $\begin{array}{l}\text { - trudności w zapamiętaniu sekwencji czyn- } \\
\text { ności; } \\
\text { - trudności z zachowaniem się w sposób } \\
\text { adekwatny dla danej sytuacji; } \\
\text { - trudność w przewidywaniu konsekwencji } \\
\text { własnych zachowań; } \\
\text { - opóźnienie lub zupełny brak rozwoju mo- } \\
\text { wy; } \\
\text { - występowanie zaburzeń mowy, } \\
\text { - nieumiejętność dokonywania wyborów }\end{array}$ \\
\hline
\end{tabular}

Źródło: opracowanie własne na podstawie: E. Pisula, Autyzm. Od Badań mózgu do praktyki psychologicznej, Gdańskie Wydawnictwo Psychologiczne, Sopot 2012, s. 71; A. Rynkiewicz, Zespót Aspergera. Inny mózg, inny umyst, Wydawnictwo HARMONIA, Gdańsk 2009, s. 44; K. Walsh, Neuropsychologia kliniczna, Wydawnictwo Naukowe PWN, Warszawa 2000, s. 147.

\section{B. Płaty skroniowe}

Hipoteza: Uszkodzenie płatów skroniowych

Autorzy badań: Giedd, Shaw, Wallace, Gogtay, Lenroot - 2006

\begin{tabular}{|c|c|}
\hline \multicolumn{1}{|c|}{ Funkcja sprawowana przez obszar: } & \multicolumn{1}{c|}{$\begin{array}{c}\text { Konsekwencje uszkodzenia obszaru } \\
\text { u osób z ASD: }\end{array}$} \\
\hline $\begin{array}{l}\text { - odpowiadają za słuch i rozumienie mowy, } \\
\text { a także za gramatykę, prozodię; }\end{array}$ & $\begin{array}{l}\text { ograniczenie (lub zupełny brak) rozumie- } \\
\text { nia mowy; }\end{array}$ \\
- odpowiada za rozpoznawanie obiektów; & - wypowiedzi niegramatyczne; \\
- jest odpowiedzialny za analizę zapachów & - nieprawidłowa prozodia języka; \\
& - zaburzenia słuchu fonematycznego; \\
& - trudność w rozpoznawaniu dźwięków \\
& (w tym również brak reakcji na własne imię) \\
\hline
\end{tabular}

Źródło: opracowanie własne na podstawie: E. Pisula, Autyzm. Od Badań mózgu do praktyki psychologicznej, Gdańskie Wydawnictwo Psychologiczne, Sopot 2012, s. 71; A. Rynkiewicz, Zespót Aspergera. Inny mózg, inny umyst, Wydawnictwo HARMONIA, Gdańsk 2009, s. 44; K. Walsh, Neuropsychologia kliniczna, Wydawnictwo Naukowe PWN, Warszawa 2000, s. 147. 
cd. tab. 3

\section{Móżdżek}

Hipoteza: Hipoplazja móżdżku i zredukowana ilość substancji szarej lub białej w różnych jej częściach

Autorzy badań: McAlonan, Cheung, Cheung, Suckling, Lam i in. - 2005; Toal, Bloemen, Deeley, Tunstall, Daly i in. - 2009; Mostofsky, Powell, Simmonds, Goldberg, Caffo i in. - 2009

\begin{tabular}{|l|l|}
\hline Funkcja sprawowana przez obszar: & $\begin{array}{l}\text { Konsekwencje uszkodzenia obszaru } \\
\text { u osób z ASD: }\end{array}$ \\
\hline - moduluje napięcie mięśni i wpływa na & - trudność w utrzymywaniu równowagi \\
utrzymanie prawidłowej postawy i rów- & $\begin{array}{c}\text { oraz dysfunkcje motoryczne; } \\
\text { nowagi ciała; }\end{array}$ \\
- niezdolność do skupienia uwagi na szyb- & ko zmieniających się słowach, gestach, \\
zyjnych & pozach i innych wskazówkach, które sy- \\
& gnalizują zmianę w strumieniu informacji; \\
& - zredukowana eksploracja przestrzenna; \\
& - nietypowe reakcje na bodźce słuchowe; \\
& - zaburzone interakcje społeczne
\end{tabular}

Źródło: opracowanie własne na podstawie: S. Baron-Cohen, P. Bolton, Autyzm. Fakty, Wydawnictwo JAK, Kraków 1999, s. 41; E. Pisula, Małe dziecko z autyzmem, Gdańskie Wydawnictwo Psychologiczne, Sopot 2010, s. 25; E. Pisula, Autyzm. Od Badań mózgu do praktyki psychologicznej, Gdańskie Wydawnictwo Psychologiczne, Sopot 2012, s. 77; B. Winczura, Jak funkcjonuje mózg dzieci z autyzmem? Neurobiologiczne ścieżki zaburzeń autystycznych, [w:] Dziecko chore. Zagadnienia biopsychiczne i pedagogiczne, red. B. Cytowska, B. Winczura, Oficyna Wydawnicza „Impuls”, Kraków 2007, s. 288.

\section{Pień mózgu - twór siateczkowy}

Hipoteza: Uszkodzenie pnia mózgu lub tworu siateczkowego

Autorzy badań: Kruk-Lasocka - 1994, 1999; Baron-Cohen - 1999; Bolton - 1999

\section{Funkcja sprawowana przez obszar:}

- odpowiedzialny jest za stan gotowości organizmu do działania;

- jest centrum "przekaźnikowym”, dzięki któremu impulsy biegnące do mózgu są przekształcane i przesyłane do odpowiednich miejsc w korze mózgowej
Konsekwencje uszkodzenia obszaru u osób z ASD:

- utrudnienia w zakresie funkcjonowania czynności poznawczych, takich jak: uwaga, myślenie inwencyjne, tworzenie wyobrażeń;

- zaburzenia w zakresie spostrzegania i tworzenia pojęć;

- brak integracji wiązania własnego doświadczenia z doznanymi wrażeniami

Źródło: opracowanie własne na podstawie: B. Winczura, Jak funkcjonuje mózg dzieci z autyzmem? Neurobiologiczne ścieżki zaburzeń autystycznych, [w:] Dziecko chore. Zagadnienia biopsychiczne i pedagogiczne, red. B. Cytowska, B. Winczura, Oficyna Wydawnicza „Impuls”, Kraków 2007, s. 286-287. 
cd. tab. 3

\section{E. Spoidło wielkie (ciało modzelowate)}

Hipoteza: Nieproporcjonalnie mała objętość spoidła wielkiego w stosunku do zwiększonej objętości kory mózgowej u dzieci z autyzmem - agenezja spoidła wielkiego (tj. znaczne zredukowanie liczby aksonów $\mathrm{w}$ jego obrębie)

Autorzy badań: Badaruddin, Andrews, Bölte, Schilmoeller, Schilmoeller i in. - 2007

\begin{tabular}{|l|l|}
\hline \multicolumn{1}{|c|}{ Funkcja sprawowana przez obszar: } & \multicolumn{1}{c|}{$\begin{array}{c}\text { Konsekwencje uszkodzenia obszaru } \\
\text { u osób z ASD: }\end{array}$} \\
\hline - przekazuje informacje pomiędzy prawą & $\begin{array}{l}\text { - trudności w zakresie interakcji i społecznej } \\
\text { komunikacji; }\end{array}$ \\
i lewą półkulą; & $\begin{array}{l}\text { - zdarza się występowanie ograniczonych } \\
\text { - odpowiada za kojarzenie } \\
\end{array}$ \\
& - trudności zachowań; \\
\hline
\end{tabular}

Źródło: opracowanie własne na podstawie: E. Pisula, Autyzm. Od Badań mózgu do praktyki psychologicznej, Gdańskie Wydawnictwo Psychologiczne, Sopot 2012, s. 77; K. Walsh, Neuropsychologia kliniczna, Wydawnictwo Naukowe PWN, Warszawa 2000, s. 50 i 72.

\section{F. Ciało migdałowate}

Hipoteza: dysproporcja między wielkością ciała migdałowatego u dzieci z autyzmem i u dzieci rozwijających się prawidłowo

Autorzy badań: Edelson - 1997

\begin{tabular}{|c|l|}
\hline \multicolumn{1}{|c|}{ Funkcja sprawowana przez obszar: } & \multicolumn{1}{|c|}{$\begin{array}{c}\text { Konsekwencje uszkodzenia obszaru } \\
\text { u osób z ASD: }\end{array}$} \\
\hline - kontrola emocji oraz zachowań agresyw- & - pojawienie się zachowań agresywnych \\
nych; & i autoagresywnych; \\
- rozpoznawanie emocji u innych ludzi & - występowanie pasywności; \\
& - pozorna „płaskość emocjonalna”; \\
& - izolacja społeczna; \\
& - zachowania przymusowe; \\
& - trudność w przystosowaniu się do no- \\
& wych wydarzeń, sytuacji i otoczenia \\
\hline
\end{tabular}

Źródło: opracowanie własne na podstawie: E. Pisula, Autyzm. Od Badań mózgu do praktyki psychologicznej, Gdańskie Wydawnictwo Psychologiczne, Sopot 2012, s. 75; A. Rynkiewicz, Zespót Aspergera. Inny mózg, inny umyst, Wydawnictwo HARMONIA, Gdańsk 2009, s. 44; B. Winczura, Jak funkcjonuje mózg dzieci z autyzmem? Neurobiologiczne ścieżki zaburzeń autystycznych, [w:] Dziecko chore. Zagadnienia biopsychiczne i pedagogiczne, red. B. Cytowska, B. Winczura, Oficyna Wydawnicza „Impuls”, Kraków 2007, s. 289. 
cd. tab. 3

\begin{tabular}{|c|c|}
\hline \multicolumn{2}{|l|}{ G. Układ limbiczny } \\
\hline \multicolumn{2}{|c|}{$\begin{array}{l}\text { Hipoteza: nadmierne zagęszczenie neuronów oraz ich mniejsze rozmiary } \\
\text { Autorzy badań: Palmen, i in. - 2004; Mosconi, Cody-Hazlett i in. - 2009; Adolphs, Baron- } \\
\text {-Cohen i Tranel - } 2012\end{array}$} \\
\hline Funkcja sprawowana przez obszar: & $\begin{array}{l}\text { Konsekwencje uszkodzenia obszaru } \\
\text { u osób z ASD: }\end{array}$ \\
\hline $\begin{array}{l}\text { - przetwarzanie bodźców o znaczeniu } \\
\text { emocjonalnym i społecznym }\end{array}$ & $\begin{array}{l}\text { - trudność w tworzeniu wspólnego pola } \\
\text { uwagi; } \\
\text { - trudność w rozpoznawaniu stanów men- } \\
\text { talnych, zwłaszcza stanów złożonych, } \\
\text { szczególnie bardziej skomplikowanych } \\
\text { emocji społecznych; } \\
\text { - trudność w nawiązywaniu kontaktu wzro- } \\
\text { kowego podczas rozmowy z innymi ludźmi }\end{array}$ \\
\hline
\end{tabular}

Źródło: opracowanie własne na podstawie, Baron-Cohen S., Bolton P., Autyzm. Fakty, Wydawnictwo JAK, Kraków 1999.s. 38; E. Pisula, Autyzm. Od Badań mózgu do praktyki psychologicznej, Gdańskie Wydawnictwo Psychologiczne, Sopot 2012, s. 74; B. Winczura, Jak funkcjonuje mózg dzieci z autyzmem? Neurobiologiczne ścieżki zaburzeń autystycznych, [w:] Dziecko chore. Zagadnienia biopsychiczne i pedagogiczne, red. B. Cytowska, B. Winczura, Oficyna Wydawnicza „Impuls", Kraków 2007, s. 289.

\section{H. Hipokamp}

Hipoteza: Zmiana w rozmiarze hipokampa w stosunku do populacji ogólnej Autorzy badań: Rojas, Smith, Benkers, Camou, Reite i in. - 2004; Aylward, Minshew, Goldstein, Honeycutt, Augustine i in. - 1999

\begin{tabular}{|c|c|}
\hline Funkcja sprawowana przez obszar: & $\begin{array}{c}\text { Konsekwencje uszkodzenia obszaru } \\
\text { u osób z ASD: }\end{array}$ \\
\hline - odpowiada za proces uczenia się i pamięć & $\begin{array}{c}\text { - niezdolność gromadzenia w pamięci no- } \\
\text { wych informacji; } \\
\text { - trudność z powiązaniem informacji no- } \\
\text { wych i wcześniej nagromadzonych; } \\
\text { - pojawienie się zachowań stereotypowych } \\
\text { i autostymulacyjnych }\end{array}$ \\
\hline
\end{tabular}

Źródło: opracowanie własne na podstawie: E. Pisula, Autyzm. Od Badań mózgu do praktyki psychologicznej, Gdańskie Wydawnictwo Psychologiczne, Sopot 2012, s. 74; B. Winczura, Jak funkcjonuje mózg dzieci z autyzmem? Neurobiologiczne ścieżki zaburzeń autystycznych, [w:] Dziecko chore. Zagadnienia biopsychiczne i pedagogiczne, red. B. Cytowska, B. Winczura, Oficyna Wydawnicza „Impuls”, Kraków 2007, s. 289. 
W tabeli 3. ukazano zaledwie kilka tez dotyczących roli uszkodzenia określonych obszarów mózgu w etiopatogenezie zaburzeń spektrum autyzmu. Hipotez tych jest znacznie więcej, niewiele jednak znajduje potwierdzenie na drodze badań naukowych, wybrano zatem te, których wiarygodność udokumentowano empirycznie.

Istnieje jeszcze jedna niezwykle ciekawa koncepcja przyczyn występowania zaburzeń spektrum autyzmu, na którą warto zwrócić uwagę. Jej twórcą jest Jean Ayres, zdaniem której symptomy występujące $\mathrm{w}$ omawianym zaburzeniu są konsekwencją zaburzeń integracji sensorycznej. Dysfunkcja procesów poznawczych powoduje, iż układ nerwowy nie jest zdolny do uporządkowania informacji, docierających do niego poprzez różne kanały sensoryczne. Dlatego też nie jest w stanie zintegrować napływających danych, a także połączyć świeżych informacji z wcześniejszymi. Skutkuje to wystąpieniem nieadekwatnej reakcji na określony, działający $\mathrm{w}$ danym momencie, bodziec. Do najcharakterystyczniejszych symptomów zaburzeń integracji sensorycznej należą: „nadaktywność oraz trudności w koncentracji uwagi, zaburzenia napięcia mięśniowego i koordynacji, a także wszelkiego rodzaju nadwrażliwość lub jej brak na hałas, dotyk, światło, zapach czy smak" 97.

Trafność owego twierdzenia znalazła swoje odzwierciedlenie $\mathrm{w}$ najnowszych kryteriach diagnostycznych Amerykańskiego Towarzystwa Psychiatrycznego - DSM-V, w których jednym z możliwych symptomów zaburzeń spektrum autyzmu są właśnie zaburzenia sensoryczne ${ }^{98}$.

Podsumowując, zaburzenia spektrum autyzmu, jako niezwykle zróżnicowane zaburzenia rozwoju, bez wątpienia mają również wieloczynnikową etiologię. Stanowiska badaczy dotyczące przyczyn autyzmu zmieniają się, prezentowane przez nich koncepcje są coraz bardziej szczegółowe i precyzyjne, mimo to nie pozwalają udzielić jednoznacznej odpowiedzi na pytanie: $\mathrm{W}$ jaki sposób do-

${ }_{97}$ B. Winczura, Jak funkcjonuje mózg dzieci..., s. 291.

98 American Psychiatric Association, Diagnostic and statistical manual of mental disorders. Fifth edition, Washington, DC, London, England 2012-2013. 
chodzi do występowania zaburzeń spektrum autyzmu u dzieci? Jednak pomimo iż przyczyny autyzmu nadal nie są znane, a zaprezentowane hipotezy wymagają dalszych weryfikacji, dużym osiągnięciem jest możliwość wyodrębnienia potencjalnych czynników ryzyka - ich znajomość, świadomość konsekwencji, jakie może mieć ich obecność dla rozwoju dziecka, a także umiejętność dostrzegania pierwszych niepokojących symptomów autyzmu, jest niezwykle ważna ze względu na możliwość przeprowadzenia diagnozy, a także podjęcia wczesnych oddziaływań terapeutycznych, które mają kluczowe znaczenie dla późniejszego funkcjonowania dziecka z zaburzeniem spektrum autyzmu.

\section{Bibliografia}

Baron-Cohen S., Bolton P., Autyzm. Fakty, Wydawnictwo JAK, Kraków 1999.

Błeszyński J., Przegląd badań genetycznych koncepcji etiologii autyzmu, „Szkoła Specjalna" 2007, nr 3.

Bobkowicz-Lewartowska L., Autyzm dziecięcy, zagadnienia diagnozy i terapii, Oficyna Wydawnicza „Impuls”, Kraków 2000

Diagnostic and statistical manual of mental disorders. Fifth edition, American Psychiatric Association, Washington, DC, London, England 2012-2013.

Frith U., Autyzm. Wyjaśnienie tajemnicy, Gdańskie Wydawnictwo Psychologiczne, Sopot 2008

Gołaska P., Etiologia zaburzeń ze spektrum autyzmu. Przeglad wybranych koncepcji, „Psychiatria i psychologia kliniczna” 2013, nr 1.

Hauser J., Dmitrzak-Węglarz M., Leksykon genetyki w psychiatrii, Termedia Wydawnictwo Medyczne, Poznań 2010.

Jagielska G., Etiologia zaburzeń autystycznych, [w:] Autyzm i zespót Aspergera, red. J. Komander, G. Jagielska, A. Bryńska., Wydawnictwo lekarskie PZWL, Warszawa 2009.

Kessick R., Autyzm i dieta. O czym warto wiedzieć, Fraszka Edukacyjna, Warszawa 2009

Młynarska M., Autyzm w ujęciu psycholingwistycznym: terapia dyskursywna a teoria umystu, Wydawnictwo Uniwersytetu Wrocławskiego, Wrocław 2008.

Mowszet K., Hutyra T., Dziecko z fenyloketonuria, [w:] Dzieci chore, niepetnosprawne i z utrudnieniami w rozwoju, red. B., Cytowska, B. Winczura, A.Stawarski, Impuls, Kraków 2008. 
Pisula E., Autyzm. Od Badań mózgu do praktyki psychologicznej, Gdańskie Wydawnictwo Pisula E., Autyzm. Przyczyny, symptomy, terapia, Wydawnictwo HARMONIA, Gdańsk 2010.

Pisula E., Małe dziecko z autyzmem, Gdańskie Wydawnictwo Psychologiczne, Sopot 2010.

Pisula E., Danielewicz D., Terapia i edukacja osób z autyzmem - historia i dzień dzisiejszy, [w:] Terapia i edukacja osób z autyzmem. Wybrane zagadnienia, red. D. Danielewicz, E. Pisula, Wydawnictwo APS, Warszawa 2003.

Rynkiewicz A., Zespót Aspergera. Inny mózg, inny umyst, Wydawnictwo HARMONIA, Gdańsk 2009.

Suchowierska M., Ostaszewski P., Bąbel P., Terapia behawioralna dzieci z autyzmem. Teoria, badania i praktyka stosowanej analizy zachowania, Gdańskie Wydawnictwo Psychologiczne, Sopot 2012.

Talaroska M., Florkowski A., Gałecki P., Zboralski K., Psychologiczne koncepcje rozwoju autyzmu, [w:] Autyzm - epidemiologia, diagnoza i terapia, red. T. Pietras, A. Witusik, P. Gałecki, Wydawnictwo Continuo, Wrocław 2010.

Walsh K., Neuropsychologia kliniczna, Wydawnictwo Naukowe PWN, Warszawa 2000.

Winczura B., Jak funkcjonuje mózg dzieci z autyzmem? Neurobiologiczne ścieżki zaburzeń autystycznych, [w:] Dziecko chore. Zagadnienia biopsychiczne i pedagogiczne, red. B. Cytowska, B. Winczura, Oficyna Wydawnicza „Impuls”, Kraków 2007.

Winczura B., Dziecko z autyzmem. Terapia deficytów poznawczych a teoria umystu, Oficyna Wydawnicza „Impuls”, Kraków 2008.

Wojciechowska A., Koncepcje autyzmu i problemy diagnostyczne - przeglad literatury, [w:] Poznańska pedagogika specjalna. Tradycje - osiagnięcia - perspektywy, red. W. Dykcik, A. Twardowski, Wydawnictwo Naukowe UAM, Poznań 2006.

Wujcik, R., Porzycka A., Witusik A., Pietras T., Neurorozwojowa hipoteza autyzmu, [w:] Autyzm - epidemiologia, diagnoza i terapia, red. T. Pietras, A. Witusik, P. Gałecki, Wydawnictwo Continuo, Wrocław 2010. 